\title{
LIÊN QUAN GIŨ̃A NỒNG Độ BILIRUBIN TOÀN PHẦN HUYẾT TƯƠNG VỚI MỨC Độ TỔN THƯƠ'NG ĐộNG MACH VÀNH TẠI BỆNH VIÊ̂N TRUNG ƯƠNG THÁI NGUYÊN
}

\author{
Bùi Thị Thu Hương*, Cao Bá Khương*, Trần Thị Mai**
}

\section{TÓM TẮT}

Bilirubin được cho là có tác dụng bảo vê trong bệnh động mạch vành. Mối liên quan giữa nồng độ Bilirubin toàn phần huyết tương với mức độ tổn thương động mạch vành cần được nghiên cứu rõ̃ hơn. Muc tiêu: Xác định mối liên quan giữa nồng độ Bilirubin toàn phần huyết tương với mức độ tổn thương động mạch vành đánh giá bằng thang điểm Gensini ở bênh nhân có chỉ định chụp động mach vành tại Bềnh viện Trung ương Thái Nguyên. Phương pháp: Nghiên cứu mô tả cắt ngang trên 84 bệnh nhân được chụp ĐMV tại Bệnh viện Trung ương Thái Nguyên từ tháng 3/2020 đến tháng 2/2021. Kết quả: Nồng độ Bilirubin toàn phần huyết tương trung bình là $12,57 \pm 5,39 \mu \mathrm{mol} / \mathrm{L}$. Không có sư khác biêt về nồng độ bilirubin trung binh giữa hai giới và các nhóm tuổi $(p>0,05)$. Nhóm có nồng đô bilirubin toàn phần huyết tương $<17,1 \mu \mathrm{mol} / \mathrm{l}$ có tỳ lệ ĐMV hẹp $\geq 50 \%$ là $88,9 \%$ cao hơn nhóm có nồng đồ bilirubin toàn phần huyết $\geq 17,1 \mu \mathrm{mol} / \mathrm{l}$, tỷ lệ hẹp $\geq 50 \%$ là $57,1 \%$. Sự khác biêt có ý nghî́a thổng kê $(\mathrm{OR}=0,2 ; 95 \% \mathrm{CI}$ : $0,05-0,54 ; p<0,01)$. Nồng độ bilirubin toàn phần trung bình huyết tương giảm dần theo mức độ nặng của tổn thương động mạch vành theo điểm Gensini mức độ nhe là 15,93 $\pm 5,17$; điểm Gensini trung bình là $12,72 \pm 5,15$; điểm Gensini mức độ nặng là $9,51 \pm 3,87$, với $p<0,001$. Có mối tướng quan nghich khá chặt giữa nồng độ Bilirubin toàn phân huyết tương với điểm số Gensini đánh giá mức độ tổn thương ĐMV ở các bênh nhân bênh mạch vành $(r=$ $0,52, p<0,05$ ). Kết luân: Nồng độ Bilirubin toàn phần trong huyết tương thấp có liên quan đến mức đô tổn thương nặng động mạch vành (hẹp $\geq 50 \%$ và theo điểm Gensini); có mối liên quan nghịch khá chăt với mức độ tổn thương động mạch vành được tính theo thang điểm Gensini $(r=-0,52, p<0,001)$.

Tư khoá: Bilirubin toàn phần, tổn thương động mạch vành, thang điểm Gensini.

\section{SUMMARY \\ RELATIONSHIP BETWEEN THE BILIRUBIN \\ TOTAL AND DEGREE OF CORONARY ARTERY DISEASE AT THAINGUYEN NATIONAL HOSPITAL}

Bilirubin is believed to have protective effects in coronary artery disease. The relationship between the total plasma bilirubin concentration and the degree of

\section{*Trường đại học Y Dược Thái Nguyên}

*Bênh viên 198

Chịu trách nhiệm chính: Bùi Thị Thu Hương

Email: huongbuithithu@tnmc.edu.vn

Ngày nhận bài: 14.01.2021

Ngày phản biên khoa hoc: 17.3.2021

Ngày duyệt bài: 29.3.2021 coronary artery damage needs to be further investigated. Objective: To determine the relationship between the concentration of total bilirubin in plasma with the level of coronary artery injury assessed by Gensini scale in patients with an indication for coronary angiography at ThaiNguyen National Hospital. Methods: Cross-sectional descriptive study on 84 patients had a coronary scan at ThaiNguyen National Hospital from March 2020 to February 2021. Results: The mean total plasma bilirubin concentration was $12.57 \pm 5.39 \mu \mathrm{mol} / \mathrm{L}$. There was no difference in mean bilirubin concentration between the sexes and the age groups $(p>0.05)$. The group with total plasma bilirubin concentration $<17.1 \mu \mathrm{mol} / \mathrm{l}$ had a narrow coronary heart rate $\geq 50 \%$, which was $88.9 \%$ higher than the group with total bilirubin concentration $\geq 17.1 \mu \mathrm{mol} / \mathrm{l}$, the rate of narrow $\geq 50 \%$ is $57.1 \%$. The difference is statistically significant (OR $=0.2 ; 95 \%$ CI: $0.05-0.54$; $\mathrm{p}<0.01)$. The mean total plasma bilirubin concentration decreased with severity of coronary artery damage according to the mild Gensini score of $15.93 \pm 5.17$; the mean Gensini score was $12.72 \pm$ 5.15 ; Gensini severity score was $9.51 \pm 3.87$, with $p$ $<0.001$. There is a quite strong inverse correlation between the concentration of total bilirubin in plasma with Gensini score assessing the level of coronary damage in patients with coronary artery disease $(r=-$ 0.52 , p <0.05). Conclusion: Low plasma bilirubin concentration is associated with severe coronary artery damage ( $\geq 50 \%$ stenosis and Gensini score); There was a fairly strong inverse relationship with the degree of coronary injury calculated on the Gensini score ( $r=$ $0.52, \mathrm{p}<0.001$ )

Keywords: Total bilirubin, coronary artery damage, Gensini score.

\section{I. ĐẶT VẤN ĐỀ}

Bệnh động mạch vành là một trong những nguyên nhân phổ biến nhất gây tử vong trên toàn thế giới. Năm 2010, khoảng 7 trong tổng số 53 triệu ca tử vong do thiếu máu cơ tim. Xơ vữa động mạch là căn bệnh gây ra hầu hết các trường hợp hội chứng mạch vành cấp tính. Khoảng $90 \%$ các trường hợp nhồi máu cơ tim bắt nguồn từ huyết khối cấp tính làm tắc nghẽn động mạch vành bị xơ vữa. Vỡ và xói mòn mảng bám được coi là nguyên nhân chính gây huyết khối mạch vành. Bilirubin một sản phẩm của quá trình thoái hóa hemoglobin đã được nghiên cứu chứng minh có tác dụng: Giãn mạch, chống oxy hóa, chống viêm, chống đột biến, điều hòa miễn dịch, chống tăng sinh và chống apoptotic trên tế bào mạch máu. Bilirubin cũng được chỉ ra là có 
tác dụng hạ lipid máu bằng cách giảm peroxy hóa lipoprotein tỷ trọng thấp ( $\mathrm{LDL}-\mathrm{C})$ trong huyết tương. Nhờ những đặc tính này, bilirubin được cho là có tác dụng bảo vệ trong bệnh động mạch vành. Mối liên quan giữa nồng độ Bilirubin toàn phân huyết tương với mức độ tổn thương động mạch vành ở các đối tượng bệnh nhân nói chung còn chưa rõ. Vì vậy, chúng tôi tiến hành nghiên cứu đề tài với mục tiêu: Xác định mối liên quan giữa nồng độ Bilirubin toàn phần huyêt tương với mức độ tổn thương động mạch vành đánh giá bằng thang điểm Gensini ở bệnh nhân có chỉ định chụp động mạch vành tại Bệnh viện Trung ương Thái Nguyên.

\section{II. ĐỐI TƯợNG VÀ PHƯƠNG PHÁP NGHIÊN CỨU}

2.1. Đối tượng nghiên cứu. $84 \mathrm{BN}$ có chỉ định chụp ĐMV tại Bệnh viện Trung ương Thái Nguyên từ tháng 03 năm 2020 đến tháng 2 năm 2021.

Tiêu chuẩn loại trừ: Bệnh nhân có bệnh lý về gan, mật, tuy cấp hoặc mạn tính, bệnh nhân suy thận, suy tim nặng NYHA III, IV, có Bilirubin toàn phần tăng đợn độc, có bệnh cơ tim giãn, có bệnh ĐM ngoại vi, có bằng chứng viêm nhiễm, hoặc các bệnh nhiễm khuẩn, có rối loạn đông máu, bệnh tự miễn, các bệnh ác tính, bệnh phổi tắc nghẽn mạn tính.

2.2. Phương pháp nghiên cứu. Nghiên cứu mô tả cắt ngang.

Cỡ mẫu thuận tiện: là toàn bộ bệnh nhân đủ tiêu chuẩn nghiên cứu.

\subsection{Thời gian địa điểm nghiên cứu}

Thời gian nghiển cứu: từ tháng 03 năm 2020 đên tháng 2 năm 2021

Địa điểm nghiên cứu: Các khoa Tim mạch, Bệnh viện Trung ương Thái Nguyên; Bộ môn Sinh hóa, Trường Đại học Y Dược Thái Nguyên.

2.4. Chỉ tiêu và tiêu chuẩn đánh giá sử dụng trong nghiên cứu:

+ Đặc điểm chung về tuổi, giới, tiền sử gia đình có người mắc bệnh mạch vành

+ Tiền sử bệnh, một số yếu tố nguy cơ của bệnh ĐMV: Hút thuốc, THA, ĐTĐ, tiền sử gia đình bị bệnh động mạch vành.

+ Xét nghiệm máu: Tất cả bệnh nhân được lấy $2,5 \mathrm{ml}$ máu lúc đói để định lượng nồng độ bilirubin toàn phần và một số chỉ số xét nghiệm sinh hoá khác. Các xét nghiệm được thực hiện tại Bộ môn Sinh hóa, Khoa Sinh hóa Bệnh viện TW Thái Nguyên trên máy AU480 của hãng Olympus, hóa chất của Beckman Coulter.

Bilirubin toàn phần huyết tương bình thường: $<17,1 \mu \mathrm{mol} / \mathrm{L}$.

+ Chụp ĐMV: Bệnh nhân được chụp động mạch vành tại Phòng Can thiệp tim mạch Bệnh viện Trung ương Thái Nguyên. Phân độ nặng của tổn thương ĐMV theo điểm số Gensini.

\section{Tính điểm theo mức độ hẹp}

25\% - 49\%: 1 điểm

$50 \%-75 \%: 2$ điểm

$75 \%-89 \%: 4$ điểm

90\% - 98\%: 8 điểm

99\%: 16 điểm

Tắc hoàn toàn: 32 điểm

Hệ số: theo vị trí tổn thương

- Thân chung x 5

- Động mạch liên thất trước: Đoạn gần x 2,5; Đoạn giữa x1,5; Vùng mõm x1; Nhánh chéo $1 \times$ 1; Nhánh chéo $2 \times 0,5$

- Động mạch mũ: Đoạn gần x 2,5; Đoạn xa $x 1$; Nhánh bờ $x 1$; Nhánh sau dưới $x 1$; Nhánh sau bên $x 0,5$;

- Động mạch vành phải $x 1$

Điểm Gensini của bệnh nhân là tổng số điểm Gensini của toàn bộ các tổn thương sau khi nhân hệ số. Đánh giá mức độ tổn thương động mạch vành theo thang điểm Gensini score được chia thành 3 mức độ như sau: tổn thương nhe (0 - 23 điểm), tổn thương trung bình (24-54 điểm), tổn thương nặng (>54 điểm). Số nhánh ĐMV tổn thương: 1,2 hay 3 nhánh, Mức độ hẹp ĐMV: $>50 \%$ hay dưới $50 \%$.

2.6. Kỹ thuật thu thập số liệu: số liệu được ghi chép, thu thập lại thông qua hồ sơ bệnh án của bệnh nhân (theo mẫu).

2.7. Phương pháp xử lý số liệu. Số liệu của nghiên cứu được xử lý bằng phần mềm SPSS 25.0

2.8. Đạo đức trong nghiên cứu

- Nghiên cứu được thông qua Hội đồng Y đức của Bềnh viện

- Được sự đồng ý tham gia của bệnh nhân.

\section{KẾT QUẢ NGHIÊN CỨU}

Bảng 1. Đặc điểm chung của nhóm đôi tượng nghiên cứu

\begin{tabular}{|c|c|c|}
\hline & $\begin{array}{l}\text { Thông số } \\
\text { nghiên cứu }\end{array}$ & $\begin{array}{c}\text { Giá trị }(X \pm S D) \\
\text { hoặc } n(\%)\end{array}$ \\
\hline \multirow{6}{*}{$\begin{array}{c}\text { Đăc } \\
\text { điểm } \\
\text { chung } \\
\text { và các } \\
\text { yếu tố } \\
\text { nguy } \\
\text { cớ }\end{array}$} & $\begin{array}{l}\text { Tống số bệnh } \\
\text { nhân }\end{array}$ & 84 \\
\hline & Tuối (năm) & $69,3 \pm 10,7$ \\
\hline & Nam/nữ & $53(63,1) / 31(36,9)$ \\
\hline & Tiền sử ĐTĐ & $11(13,1)$ \\
\hline & Tiền sử THA & $58(69,0)$ \\
\hline & $\begin{array}{l}\text { Tần số tim } \geq \\
100 \mathrm{ck} / \text { phút }\end{array}$ & $16(19,0)$ \\
\hline \multirow{3}{*}{$\begin{array}{l}\text { Vị trí } \\
\text { tổn } \\
\text { thương } \\
\text { ĐMV }\end{array}$} & ĐMV phải & $55(65,5)$ \\
\hline & $\begin{array}{c}\text { Thân chung } \\
\text { ĐMV trái }\end{array}$ & $6(7,1)$ \\
\hline & ĐM liên thất & $71(84,5)$ \\
\hline
\end{tabular}




\begin{tabular}{|c|c|c|}
\hline & trước & \\
\cline { 2 - 3 } & ĐM mũ & $42(50,0)$ \\
\hline \multirow{2}{*}{$\begin{array}{c}\text { Điểm } \\
\text { Gensini }\end{array}$} & Nhẹ $(<=23)$ & $28(33,3)$ \\
\cline { 2 - 3 } & $\begin{array}{c}\text { Trung bình } \\
(24-54)\end{array}$ & $24(28,6)$ \\
\cline { 2 - 3 } & Nặng $(>=54)$ & $32(38,1)$ \\
\hline
\end{tabular}

Nhân xét: Tuối trung bình của nhóm nghiên cứu là $69,3 \pm 10,7$ tuổi, nam giới chiếm $63,1 \%$, Bệnh nhân tổn thương ĐM liên thất trước chiếm tỳ lệ cao nhất (84,5\%). Điểm Gensini phân độ nặng chiếm tỷ lề cao nhất 38,1\%.

Bảng 2. Nồng độ Bilirubin toàn phân huyêt tương theo tuôii, giới

\begin{tabular}{|c|c|c|c|c|}
\hline \multicolumn{2}{|c|}{ Đắc điểm } & n & $\begin{array}{c}\text { Bilirubin TP } \\
(\mu \mathrm{mol} / \mathrm{L})\end{array}$ & \multirow{2}{*}{ p } \\
\hline \multirow{2}{*}{ Giới } & Nam & 53 & $13,19 \pm 58$ & \multirow{2}{*}{$0,139 *$} \\
\cline { 2 - 4 } & Nữ & 31 & $11,5 \pm 4,97$ & \\
\hline \multirow{3}{*}{ Tuổi } & $<50$ & 2 & $11,9 \pm 10,47$ & \multirow{2}{*}{$0,487 * *$} \\
\cline { 2 - 4 } & $50-69$ & 38 & $13,34 \pm 5,39$ & \\
\cline { 2 - 4 } & $\geq 70$ & 40 & $11,98 \pm 5,29$ & \\
\hline
\end{tabular}

*Mann-Whitney test,

** Kruskal-Wallis test

Nhânn xét: Không có sự khác biệt về nông độ bilirubin toàn phân huyết tương trung bình giữa hai giới, các nhóm tuổi $(p<0,05)$.

Bảng 3. Nông độ Bilirubin toàn phân huyêt tương theo mức độ hẹp ĐMV

\begin{tabular}{|c|c|c|c|}
\hline $\begin{array}{r}\text { Mức độ tốn } \\
\text { thương } \\
\text { Bilirubin TP }\end{array}$ & $\begin{array}{c}\text { Hep }< \\
\mathbf{5 0 \%}\end{array}$ & $\begin{array}{c}\text { Hẹp } \geq \\
\mathbf{5 0 \%}\end{array}$ & Tổng \\
\hline$<17,1 \mu \mathrm{mol} / \mathrm{l}$ & $7(11 \%)$ & $\begin{array}{c}56 \\
(88,9 \%)\end{array}$ & $\begin{array}{c}63 \\
(100 \%)\end{array}$ \\
\hline$\geq 17,1 \mu \mathrm{mol} / \mathrm{l}$ & 9 & 12 & 21 \\
$(42,9 \%)$ & $(57,1 \%)$ & $(100 \%)$ \\
\hline Tổng & 16 & 68 & 84 \\
$(19,0 \%)$ & $(81 \%)$ & $(100 \%)$ \\
\hline \multicolumn{2}{|c|}{ OR=0,2; 95\% CI: $0,05-0,54 ; \mathrm{p}<0,01$} \\
\hline
\end{tabular}

*Mann-Whitney test

Nhân xét: Nhóm có nồng độ bilirubin toàn phần huyết tương $<17,1 \mu \mathrm{mol} / \mathrm{l}$ có tỷ lệ ĐMV hẹp $\geq 50 \%$ là $88,9 \%$ cao hơn nhóm có nồng độ bilirubin toàn phân huyết $\geq 17,1 \mu \mathrm{mol} / \mathrm{l}$, tỷ lệ hẹp $\geq 50 \%$ là $57,1 \%$. Sự khác biệt có ý nghĩa thống kê $(\mathrm{OR}=0,2 ; 95 \%$ CI: 0,05-0,54; $\mathrm{p}<0,01)$.

Bảng 4. Nồng độ Bilirubin toàn phân huyết tương theo thang điểm Gensini

\begin{tabular}{|c|c|c|c|}
\hline $\begin{array}{c}\text { Mức độ nắng } \\
\text { của tổn } \\
\text { thương } \\
\text { DMVtính theo } \\
\text { thang điểm } \\
\text { Gensini }\end{array}$ & $\mathbf{n}$ & $\begin{array}{c}\text { Nông độ } \\
\text { bilirubin Tp } \\
\text { trung bình } \\
(\mu \mathrm{mol} / \mathrm{L})\end{array}$ & $\mathbf{p}$ \\
\hline $\begin{array}{c}\text { Nhẹ (0-23 } \\
\text { điểm) }\end{array}$ & 28 & $15,93 \pm 5,17$ & \multirow{2}{*}{$<0,001^{* *}$} \\
\hline Trung bình & 24 & $12,72 \pm 15$ & \\
\hline
\end{tabular}

\begin{tabular}{|c|c|c|c|}
\hline $\begin{array}{c}\text { (24-53 điểm) } \\
\text { Nặng } \\
\text { ( } \geq 54 \text { điểm) }\end{array}$ & 32 & $9,51 \pm 3,87$ & \\
\hline Tống & 84 & $12,57 \pm 5,39$ & \\
\hline
\end{tabular}

\section{$* *$ : Kruskal-Wallis test}

Nhânn xét: Nông độ bilirubin toàn phân trung bình huyết tương giảm dần theo mức độ nặng của tổn thương động mạch vành: điểm Gensini thấp là 15,93 $\pm 5,17$; điểm Gensini trung bình là $12,72 \pm 5,15$; điểm Gensini cao là 9,51 $\pm 3,87$, sự khác biệt có ý nghĩa thống kê với $p<0,001$.

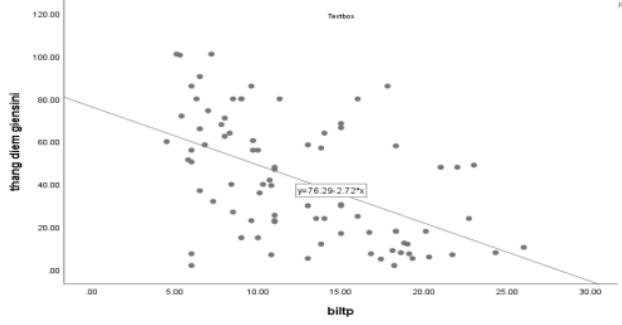

Biểu đồ 1. Môii liên quan nông độ Bilirubin toàn phân huyêt tương với điểm Gensini (điểm phân độ năng của tổn thương ĐMV)

Nhận xét: Biêuu đồ trên cho thấy có mối quan hệ tuyến tính giữa nồng độ Bilirubin toàn phân huyết tương và điểm Gensini. Đưa vào mô hình hôi quy tuyến tính với Bilirubin toàn phân là biến độc lập và điểm Gensini là biến phụ thuộc, chúng ta có phương trình sau:

Điểm Gensini $=-2,72 *$ nồng độ Bilirubin toàn phân huyết tương $+76,29$

Như vậy, khi nồng độ Bilirubin toàn phân huyết tương tăng thêm 1 umol/l, điểm Gensini sẽ giảm tương ứng 2,72 điểm. Có mối tương quan nghịch khá chặt giữa nồng độ Bilirubin toàn phân huyết tương với điểm số Gensini đánh giá mức độ tổn thương ĐMV ở các bệnh nhân bệnh mạch vành $(r=-0,52, p<0,001)$.

\section{BÀN LUẬN}

Đặc điểm tuổi, giới và các yếu tố nguy cơ. Nghiên cứu trên 84 bệnh nhân có chỉ định chụp động mạch vành, tuổi trung bình của đối tượng nghiên cứu là 69,3 \pm 10,7 tuổi. Kết quả nghiên cứu về độ tuổi trung bình của chúng tôi tương tự Hoàng Công Tùng tuổi trung bình bệnh nhân có bệnh mạch vành là $68 \pm 12$ tuổi [4]; cao hơn so với Phạm Mạnh Hùng tuổi trung bình bệnh nhân được chụp động mạch vành là 64,62 10,06 [5]; Nguyễn Phương Anh và cộng sự tuổi trung bình là $64,25 \pm 8,95$ [6], tuy nhiên cũ̃ng là hợp lý vì bệnh mạch vành thường gặp ở lứa tuổi trên 60.

Nghiên cứu của chúng tôi gặp nhiều hơn ở nam giới chiếm tỷ lệ $63,1 \%$, kết quả này cũng 
tương tự các nghiên cứu khác: Phạm Mạnh Hùng (69,9\%)[5], Nguyễn Phương Anh (66,7\%) [6]. Do những khác biệt về đặc điểm sinh lý, các thói quen không tốt ở nam giới như hút thuốc lá, rượu bia làm gia tăng tỷ lệ bệnh động mạch vành, do vậy nam hay bị bệnh động mạch vành hơn so với nữ.

Tăng huyết áp: Có $69,0 \%$ trong nghiên cứu của chúng tôi trên 84 bệnh nhân bị THA. Kết quả nghiên cứu này cao hơn so với nghiên cứu của Phạm Mạnh Hùng 50,9\%, Hoàng Công Tùng: $54,3 \%$ [4], có lẽ một phần lý do tuổi trung bình nghiên cứu của chúng tôi lớn hơn (69,3 $\pm 10,7$ tuổi).

Đái tháo đường: Trong nghiên cứu của chúng tôi có $13,1 \%$ bệnh nhân mắc bệnh ĐTĐ. Tỷ lệ này thấp với các tác giả khác: Nguyễn Phương Anh [6]: 17,6\%, Hoàng Công Tùng: 18,6\% [4].

Đặc điểm Bilirubin toàn phân huyết tương theo tuổi và giới. Nồng độ Bilirubin toàn phần huyết tương trung bình của giới nam là $13,19 \pm 5,58 \mu \mathrm{mol} / \mathrm{L}$, hàm lượng Bilirubin toàn phần trung bình của giới nữ là $11,5 \pm$ $4,97 \mu \mathrm{mol} / \mathrm{L}$. So sánh trung bình giữa 2 giới nam và nữ không có sự khác biệt $(p>0,05)$. Kết quả này tương tự với nghiên cứu của Jaechan Leem (2014) [7].

So sánh hàm lương lượng Bilirubin TP theo 3 nhóm này chúng tồi thây Bilirubin toàn phần có xu hướng giảm giữa nhóm tuổi 50-69 với nhóm $\geq 70$ tuổi $(13,34 \pm 5,39 \mu \mathrm{mol} / \mathrm{L}$ so với $11,98,87$ $\pm 5,29 \mu \mathrm{mol} / \mathrm{L})$, nhóm <50 tuổi do cõ mấu quá nhỏ (2 bệnh nhân) nên số liệu có lẽ chưa thể hiện chính xác (đây cũng là hạn chế của đề tài). Kểt quả của chúng tôi tương tự so với nghiên cứu của Pham Manh Hùng cho thấy có sự khác biêt về nồng độ bilirubin toàn phần huyết tương giữa các nhóm tuổi $(p<0,05)$ nhưng cũng chỉ so sánh trên 2 nhóm tuối 50-69 và $\geq 70$ tuổi, nghiên cứu của Akboga và Ömer Sahin cũng thây tuổi càng lớn hàm lượng Bilirubin toàn phần càng thấp [8], [9].

Liên quan giữa nồng độ bilirubin huyết tương và điểm Gensini. Kểt quả nghiên cứu của chúng tôi cho thây: Nhóm có nồng đô bilirubin toàn phần huyết tương $<17,1 \mu \mathrm{mol} / / \mathrm{l}$ có tỷ lệ ĐMV hẹp $\geq 50 \%$ là $88,9 \%$ cao hơn nhóm có nồng độ bilirubin toàn phần huyết $\geq 17,1$ $\mu \mathrm{mol} / \mathrm{l}$, tỷ lệ hẹp $\geq 50 \%$ là $57,1 \%$. Sự khác biệt có ý nghĩa thống kê (OR=0,2; $95 \%$ CI: 0,05$0,54 ; p<0,01)$. Kết quả này cho thây nồng độ Bilirubin toàn phần huyết tương thấp hơn bình thường làm tăng nguy cơ tổn thương nặng động mạch vành (hẹp $\geq 50 \%$ ).
Bệnh ĐMV là hẹp hoặc tắc nghẽn các động mạch và các mạch - nguồn cung cấp oxy và chất dinh dưỡng cho tim. Phần lớn các nghiên cứu chỉ dựa vào số lượng mạch máu hẹp và mức độ hẹp. Trong nghiên cứu này, chúng tôi sử dụng hệ thống tính điểm Gensini nhằm đánh giá khái quát và toàn diện hơn về mức độ tổn thương ĐMV ở từng bệnh nhân. Nếu có nhiều ĐM bị tổn thương, mức độ hẹp lớn, tương ứng với chỉ số Gensini càng cao thì mức độ tổn thương ĐMV càng nặng. Trong nghiên cứu này, nồng độ bilirubin toàn phần trung bình huyết tương giảm dân theo mức độ nặng của tổn thương động mạch vành: điểm Gensini mức độ nhe là $15,93 \pm$ 5,17 ; điểm Gensini trung bình là $12,72 \pm 5,15$; điểm Gensini mức độ nặng là 9,51 $\pm 3,87$, sự khác biệt có ý nghĩa thống kê với $p<0,001$. Điều này cho thấy

Theo kết quả nghiên cứu chúng tôi thấy có mối quan hệ tuyến tính giữa nồng độ Bilirubin toàn phần huyết tương và điểm Gensini. Đưa vào mô hình hồi quy tuyến tính với Bilirubin toàn phần là biến độc lập và điểm Gensini là biến phụ thuộc, chúng ta có phương trình: Điểm Gensini $=-2,72 *$ nồng độ Bilirubin toàn phần huyết tương $+76,29$. Như vậy, khi nồng độ Bilirubin toàn phần huyết tương tăng thêm $1 \mu \mathrm{mol} / \mathrm{l}$, điểm Gensini sẽ giảm tương ứng 2,72 điểm. Có mối tương quan nghich khá chăt giữa nồng đô Bilirubin toàn phần huyết tương với điểm số Gensini đánh giá mức độ tổn thương ĐMV ở các bệnh nhân bệnh mạch vành $(r=-0,52$, $\mathrm{p}<0,001)$. Kết quả nghiên cứu của chúng tôi cũng phù hợp với các nghiên cứu gần đây của Chun-Chin Chang (2016) và cộng sự $(r=-0,28$; $p<0,05)[2]$. Akboga và cộng sự (2015) nghiên cứu trên 1501 bênh nhân được chẩn đoán là bệnh ĐMV ổn định có kết quả $(r=-0.173$, $\mathrm{p}<0,001)$ có mối tương quan ở mức độ nhẹ [8]. Theo nghiên cứu này đã đưa ra kết luận rằng Bilirubin toàn phần độc lập có mối liên quan nghịch với mức độ xơ vữa ĐMV ở BN đau ngực ổ định, khi hàm lượng Bilirubin toàn phần càng thấp thì mức đô xơ vữa ĐMV càng năng. Wei và cộng sự. (2012) cũng cho kết quả tương tư với mối tương quan nghịch có ý nghĩa giữa bệnh động mạch vành và bilirubin toàn phần $(n=$ 1260) ở những bệnh nhân được chụp mạch vành. Kết quả nghiên cứu của chúng tôi tương tự nghiên cứu của Ömer Sahin và cộng sự (2013) cho thấy hàm lượng Bilirubin toàn phần trong huyết tương có mối tương quan nghịch với mức độ tổn thương ĐMV ở bệnh nhân nhồi máu 
cơ tim không ST chênh lên, hệ số tương quan $(r=-0,495 ; p<0,05)[9]$.

Mặc dù các yếu tố nguy cơ chính đã được xác định đối với xơ vữa động mạch, bao gồm tăng huyết áp (HTN), tăng lipid máu, đái tháo đường (DM), hút thuốc lá, v.v., là căn nguyên của bệnh động mạch vành. Tuy nhiên, ngày càng có nhiều bằng chứng từ các nghiên cứu cho thấy có nhiều yếu tố khác nữa cũng là nguy cơ của bênh mach vành, trong đó có nồng độ bilirubin toàn phần huyết tương. Nồng độ bilirubin huyết tương cao hơn có liên quan đến khả năng chống lai thiếu máu cục bộ cơ tim ở những bênh nhân bị tắc mạch vành toàn bộ mãn tính [1].

\section{KẾT LUÂN}

Nồng độ Bilirubin toàn phần trong huyết tương thấp có liên quan đến mức độ tổn thương nặng động mạch vành (hẹp $\geq 50 \%$ và theo điểm Gensini); có mối liên quan nghịch khá chặt với mức độ tổn thương động mạch vành được tính theo thang điểm Gensini $(r=-0,52, p<0,001)$.

KIẾN NGHI. Nên làm xét nghiệm Bilirubin toàn phần thương quy ở bệnh nhẩn có bệnh động mạch vành để có thêm yếu tố tiên lượng mức độ tổn thương động mạch vành.

LờI CẢM ON. Xin trân trọng cảm ơn Ban Giám Đốc, Hội đồng Khoa học, Khoa Tim mạch, Bộ môn Sinh hóa và các đồng nghiệp tại Bệnh viện Trung ương Thái Nguyên đã giúp chúng tôi hoàn thành nghiên cứu này.

\section{TÀI LIÊU THAM KHẢO}

1. Khalil T. S., Ibrahim W. A., Elmalla M. A. A. (2019), Serum Bilirubin as a Predictor of Coronary Artery Disease Severity in Patients
Undergoing Primary Percutaneous Coronary Intervention, World Journal of Cardiovascular Diseases, 9, 309-323.

2. Gensini G.Goffredo (1983), "A more meaningful scoring system for determining the severity of coronary heart disease", The American Journal Cardiology, 51(3), pp. 606.

3. Rostami R, Mahdi Najafi M, Sarami R, et al (2017) "Gensini scores and well-being states among patients with coronary artery disease", ARYA Atheroscler,13(5):205-210.

4. Hoàng Công Tùng (2018), "Nồng đô aolipoprotein $b$ huyết tương ở bệnh nhân mắc bênh tim thiếu máu cực bô điều trị tại Bênh viên Trung ương Thái Nguyên", Luân văn thạc sỹ y hoc, Trường Đại học Y Dược Thái Nguyên.

5. Pham Manh Hùng, Pham Nhât Minh, Horn Sophea, Nguyến Hoàng Khánh (2016), "Tìm hiếu mối liên quan giữa hàm lương bilirubin toàn phân trong huyết tương và mức độ tổn thương động mạch vành", Tạp chí Tim mạch học Việt Nam, số 77, p.42-49.

6. Nguyển Phương Anh, Phạm Mạnh Hùng (2010), Nghiên cứu vai trò của siêu âm trong lòng mạch (ivus) trong đánh giá tổn thương hẹp động mạch vành mức độ vừa, Tạp chí Tim mạch học Viêtt Nam, Số 53, p. 68-78.

7. Leem J , Eun Hee Koh, Jung Eun Jang et al (2015), Serum Total Bilirubin Levels Provide Additive Risk Information over the Framingham Risk Score for Identifying Asymptomatic Diabetic Patients at Higher Risk for Coronary Artery Stenosis, Diabetes Metab J;39:414-423

8. Akboga, M.K., et al., Association of serum total Bilirubin level with severity of coronary atherosclerosis is linked to systemic inflammation. Atherosclerosis, 2015. 240(1): p. 110-4

9. Şahin, Ö., et al., Relation between Serum Total Bilirubin Levels and Severity of Coronary Artery Disease in Patients with Non ST Elevation Myocardial Infarction. Journal of the American College of Cardiology, 2013. 62(18_S2): p. C217-C218.

\title{
KHẢO SÁT Độ DÀI Cổ TỬ CUNG Ở 3500 THAI PHU CÓ TUỔI THAI TỪ 19-23 TUẦ 6 NGÀY BẰNG SIÊU ÂM QUA ĐƯỜNG ÂM ĐẠO
}

\author{
Vũ Bá Quyết*, Nguyễn Xuân Hợi*, Đào Thị Hoa*, \\ Đinh Bích Thủy*, Nguyễn Thị Huyền Linh*
}

\section{TÓM TẮT.}

Mục tiêu: Khảo sát độ dài cổ tử cung (CTC) ở 3500 thai phu có tuổi thai từ 19- 23 tuân bằng siêu âm qua đường âm đạo. Đối tượng và phương pháp

*Bệnh viện Phụ Sản Trung ương Chịu trách nhiệm chính: Vũ Bá Quyết Email: Quyetvb2000@yahoo.com Ngày nhận bài: 18.01.2021

Ngày phản biên khoa họ: 12.3 .2021 Ngày duyệt bài: 22.3.2021 nghiên cứu: nghiên cứu mô tả cắt ngang, 3500 thai phu đến khám thai tại Khoa Khám bênh - BVPSTW có tuổi thai từ $19-23$ tuần phù hợp với tiêu chuẩn lựa chon và tiêu chuẩn loai trừ. Các thai phu được khám lâm sàng, siêu âm hình thái thi nhi và đo độ dài cổ tử cung trong khoảng thời gian từ tháng 02/2019 đến tháng 03/2021. Kết quả nghiên cứu: Độ dài CTC trung bình của 3500 thai phụ có tuổi thai từ 19-23 tuần là $35,8 \pm 5,5 \mathrm{~mm}$, không có sư khác biêt về độ dài CTC trung bình giữa các tuần thai. Độ dài CTC trung bình ở nhóm đẻ đủ tháng là $36,5 \pm 5,7 \mathrm{~mm}$, độ dài CTC trung bình ở nhóm có tiền sử đẻ non là $35,2 \pm 6,3$ mm; 